\title{
'n Etiek van liefde: Die etiese perspektiewe van die Heidelbergse Kategismus
}

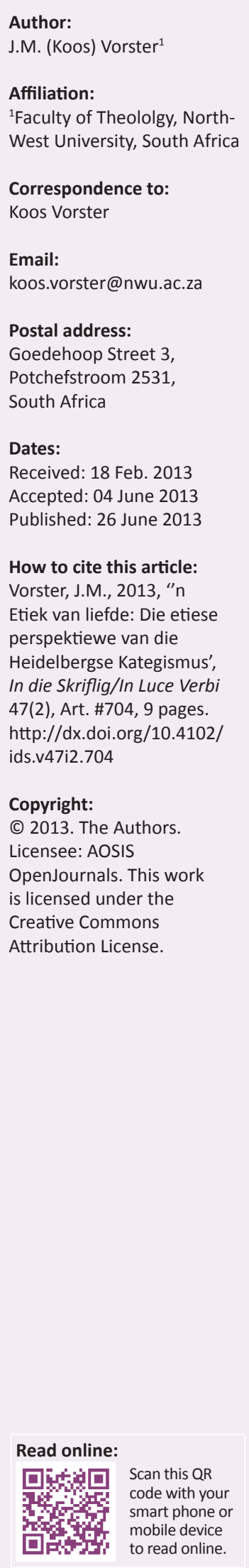

Hierdie artikel behandel die etiese perspektiewe van die Heidelbergse Kategismus - een van die prominente belydenisskrifte in die gereformeerde tradisie. Die etiese relevansie is ingebed in die konfessie se verklaring van die tien gebooie. Die artikel verduidelik dat die etiek van die Heidelbergse Kategismus ten diepste ' $n$ karakteretiek is en dat dit gelowiges oproep tot 'n etiek van liefde. Hierdie liefde sluit in liefde vir die verbondsgemeenskap, die bediening van die Woord, die heiligheid van God en die waardigheid van mense, die gemeenskap van die gelowiges, gesag, die lewe, die huwelik, privaatbesit en arbeid asook waarheid en geregtigheid. As gevolg van die sinekdogeekarakter van die wet is hierdie etiek van liefde vandag baie relevant.

An ethics of love: The ethical relevance of the Heidelberg Catechism. This article deals with the ethical relevance of one of the prominent confessions in the reformed tradition, namely the Heidelberg Cathechism. The ethical relevance lies in the confession's elucidation of the ten commandments and its application to moral conduct. The article explains that the ethics of the Heidelberg Catechism is essentially a virtue ethics calling for an ethics of love. This love should include love for the covenantal communion, ministry of the Word, the holiness of God and the dignity of people, the communion of the saints, authority, life, marriage, private property and labour, and truth and justice. Due to the synecdochical character of the ten commandments this ethics of love is highy relevant in the present times.

\section{Inleiding}

Die Reformasie wat Calvyn en sy volgelinge in die sestiende eeu en daarna teweeggebring het, het nie net diepgaande en ingrypende veranderings in die Teologie ingelui nie, maar dit het ook gelei tot verreikende ontwikkelings in die samelewings waarin dit posgevat het. Verskeie navorsers van die Reformasie van Calvyn toon aan dat geen maatskaplike terrein (bv. die politiek, ekonomie of die regte) onaangetas gelaat is deur die maatskappy-kritiese perspektiewe wat hulle navolgers op grond van hulle teologiese insigte die wêreld ingestuur het nie. Benewens die klassieke werke van Bohatec (1934 \& 1962), McNeil (1965) en Leith (1989) in hierdie verband, kan ook gewys word op die onlangse werk van Witte (2007:81). Hy toon aan dat die sosiale denke van Calvyn, soos dit verder deur Beza, Althusius, Milton en andere uitgebou is, demokrasie bevorder het en selfs moderne konstitusionele denke ten grondslag lê. Die Reformasie van Calvyn het die monargie en die idee van 'n kerkstaat deurbreek en die fundamentele regte van mense saam met die verantwoordelikheid van die burgerlike owerhede deeglik in die moderne staatkundige denke aan die orde gestel. Van Drunen (2010) sê:

Reformed Christianity is widely respected for having a vibrant tradition of social thought. Whether the examples taken from John Calvin's Geneva, Puritan England, or Abraham Kuyper in the Netherlands, friend and foe alike often admire Reformed Christianity for inspiring its adherents to think not anly about Ecclesiatical piety but also about the wide spectrum of political and cultural affairs. (bl. 1)

Die gereformeerde konfessies en in die besonder die Heidelbergse Kategismus, adem hierdie gees.

In hulle ondersoek in hierdie verband wys Grabill (2006:98) en Van Drunen (2010:67) op die ingrypende invloed van Calvyn se siening van die natuurreg. Sistematiese uiteensettings van sy idee van die lex naturae is deur sommige van sy volgelinge soos Vermigli, Zanchi, Turretin en Althusius (Grabill 2006:15; Witte 2007:143) verskaf. Die konsep ius naturalis of lex naturae, tesame met sy sienings oor die beginsels van die algemene genade, die leer oor die voorsienigheid van God en die regte van individue, vorm die grondslag waarop 'n mens die Reformasie van Calvyn ten opsigte van die burgerlike regering en wat daarmee saamhang, moet verstaan. Turretin (1997: Inst. 1.3.4) het veral hiertoe bygedra. Uiteindelik het die idee uitgeloop op die Romeins-Hollandse reg van Grotius. 
Die Reformasie van Calvyn was dus 'n teologiese en sosiale reformasie. Binne hierdie klimaat het die Heidelbergse Kategismus in 1563 ontstaan. ${ }^{1}$ Net soos die teologie en sosiale denke van Calvyn en sy volgelinge, wys die Heidelbergse Kategismus op die diep dimensies van gereformeerde teologie, onder andere die Godsleer en die Verlossingsleer. Op grond daarvan wys hierdie belydenisskrif ook op die sosiale implikasies van hierdie teologiese perspektiewe. Die doel van hierdie artikel is om die sosiaal-etiese perspektiewe van hierdie belydenisskrif in oënskou te neem en die belang daarvan te evalueer. Die sentraal-teoretiese argument is dat die etiese perspektiewe van die Heidelbergse Kategismus onder woorde gebring kan word as 'n karakteretiek van liefde wat in die een-en-twintigste eeu nog steeds uiters relevant is en deur middel van die prediking ' $n$ waardevolle bydrae in die huidige sosiaal-etiese diskoerse kan lewer. Soos in die tyd van die Reformasie, is die etiek soos dit in die Heidelbergse Kategismus verwoord is, brandend aktueel (Van 't Spijker 2009:251). Hierdie etiek bly relevant al worstel die moderne etici met makro-etiese vraagstukke soos die etiek van die ekonomie, eko-etiek, bio-etiek en die politieke etiek van die moderne konstitusionele denke.

Die verstaan van die etiese perspektiewe van die Heidelbergse Kategismus is afhanklik van die indeling wat in die dokument gevolg word ten opsigte van die beredenering van die reformatoriese teologie. Hierdie indeling berus op die breë indeling van die brief aan die Romeine. Die beredenering volg die logiese gang van die bespreking van die mens se ellendige staat voor God, die verlossing deur Christus, die gelowige aanvaarding daarvan as die enigste weg tot saligheid en die implikasies van hierdie totale verlossing vir die lewe van die gelowige en die samelewing (HK 2003:34, 36 \& 58). Hoewel flitse van die Christelike etiek na vore kom in die deel wat die ellende en verlossing bespreek soos in die verklaring van die Apostoliese Geloofsbelydenis, word die etiese perspektiewe grootliks in die derde deel aangetref. Hierdie deel handel oor die gelowige se dankbaarheidslewe en die implikasies daarvan vir die roeping van die gelowige in die samelewing. Hierin word die aandag op die wet in sy sinekdogeekarakter gevestig en die gebed as 'die vernaamste deel van die dankbaarheid wat God van ons eis' (HK 2003:68). Die sinekdogeekarakter van die wet verwys na die wye bedoeling daarvan ten spyte van die gebruik van 'n sin of enkele sinsnedes om 'n saak aan die orde te stel (De Bruyn 1992:19; vgl. ook Douma 1996:12). Die sesde gebod kan as voorbeel dien: 'Jy mag nie doodslaan nie'. Oënskynlik gaan dit om moord, maar die gebod handel eintlik oor alle vorms van geweld en selfkastyding. Hierop sal later meer breedvoerig gewys word.

Die etiese perspektiewe kom duideliker aan die lig indien die verklaring van die wet en die gebed saam gelees word. Op die vraag waarom die wet van God so streng aan ons

1.Vir die doeleindes van hierdie navorsing word die Afrikaanse vertaling van die Heide Keidelbergse Kategismus gebruik soos dit in die verskillende gereformeerde in in Heidelberbse Kategismus (2003:33-72). Vir $n$ sinopsis van die Heidelbergse Kategismus en ander prominente belydenisskrifte in die gereformeerde tradisie, vergelyk Beeke en Ferguson (1999). voorgehou word as niemand dit tog in hierdie lewe kan onderhou nie, antwoord die Heidelbergse Kategismus (2003:67) dat gelowiges: 'om die genade van die Heilige Gees moet bid'. Die gebed moet wees om 'altyd meer na die ewebeeld van God vernuwe (te) word totdat ons na hierdie lewe die volmaaktheid as doel kan bereik'. Die etiese perspektiewe kan daarom afgelei word deur klem op die dankbaarheidslewe te lê as die uitvoering van die wet onder leiding van gebed.

'n Laaste inleidende opmerking handel oor die tipering van die etiese perspektiewe van die Heidelbergse Kategismus. Christelike etiek wat die Godsopenbaring in die boek van die natuur, die geskrewe Woord en die Vleesgeworde Woord as basis van etiese normering aanvaar, word gewoonlik as 'n deontologiese etiek aangedui (Geisler 2010:17). Deontologie word in die filosofiese etiek beskryf as 'n etiese teorie wat van die standpunt uitgaan dat etiese handelings ' $n$ etiek is wat op voorafopgelegde pligte gebaseer is (McNaugthon \& Rawling 2010:32). Wanneer die gebod, die verbod van elke gebod en die besondere lig van die onderskeie aspekte van die gebed onder die vergrootglas geplaas word, kan die etiese perspektiewe van die Heidelbergse Kategismus as 'n deontologiese etiek getipeer word.

Sondag 2 bring egter 'n perspektief na vore wat in die beredenering van die etiese teorie in ag geneem behoort te word. Op die vraag, 'Wat eis die wet van God van ons?', lui die antwoord uit Matteus 22:37-40 dat dit om liefde tot God en liefde tot die naaste gaan. Hierdie liefde is selfopofferende oorgawe aan God en diensvaardigheid aan die naaste. Die oorgawe aan God en die diensvaardigheid aan die naaste impliseer ' $n$ besondere liefde vir en toewyding aan die beginsels wat die wet stel. Die eise van die tien gebooie word egter in die Soteriologie gegrond. Die nakoming van die gebooie is dus nie 'n voorwaarde vir die verlossing nie, maar die gevolg van die redding in Christus. Die sondaar word eers 'n nuwe mens en dan word die tien gebooie as die eis gestel waaraan die gelowige uit dankbaarheid gehoorsaam moet wees. In die dankbaarheidslewe staan die liefde teenoor God en die naaste sentraal. Die uitvoering van die wet as die vrug van die vernuwing in Christus, gee aan die tipering van die etiek van die Heidelbergse Kategismus 'n fyner nuanse. In die lig van die verhouding verlossing -dankbaarheid kan geoordeel word dat dit benewens 'n deontologiese etiek dus ook 'n karakteretiek is. In die filosofiese etiek word 'n karakteretiek beskou as 'n etiek wat uit die morele agent se gesindheid uitvloei en deur bepaalde deugde onderlê word (Hursthouse 2010:45). As vrug van die verlossing streef die verloste na die uitlewing van die gesindheid van Christus (Fil $2: 5)$. Verlostes het ' $n$ nuwe gesindheid en hierdie gesindheid word deur Ridderbos (1971:279) getipeer as die nuwe gehoorsaamheid. Vanuit die nuwe verhouding met God, met 'n nuwe gesindheid gegrond in 'n nuwe gehoorsaamheid, benader die kinders van die Here die wet as 'n reël van hulle dankbaarheidslewe. Daarom kan die etiek van die Heidelbergse Kategismus ook as 'n karakteretiek omskryf word. 
Die etiese perspektiewe van die Heildelbergse Kategismus word in die lig van bogenoemde twee teorieë as 'n etiek van liefde geïdentifiseer - vandaar die hooftitel van hierdie artikel. Binne die raamwerk van die selfopofferende liefde aan God en die diensvaardigheid aan die naaste, word die liefde wat gelowiges vir die lewensbepalende beginsels van die wet behoort te openbaar, aangedui soos die Heidelbergse Kategismus dit verwoord. In die lig van hierdie uitgangspunt word vervolgens aandag gegee aan die Heidelbergse Kategismusindeling van die wet waarna die belydenisskrifverklaring van die uitvoering van die wet onder leiding van gebed as Christelik-etiese handelings ondersoek word. Daar word spesifiek op die sosiaaletiese implikasies gefokus om sodoende die kontemporêre relevansie van die etiek van hierdie belydenisskrif aan te dui.

\section{Die indeling van die wet}

Die karakter en gees van die etiek van liefde word in Vraag en Antwoord 93 van die Heidelbergse Kategismus omskryf, waar dit handel oor die indeling van die wet (HK 2003:61). Die wet word in twee tafels ingedeel, naamlik die eerste vier gebooie en die laaste ses gebooie. Die eerste vier handel oor die gelowiges se gedrag teenoor God en die laaste ses oor die gelowiges se gedrag teenoor hulle naaste. In hierdie antwoord word na Deuteronomium 4:13, Eksodus 34:28, Deuteronomium 10:3 en Matteus 22:37-40 verwys as die begronding daarvan. Die Heidelbergse Kategismus se verwysing na die uitspraak van Jesus is belangrik. Die groot gebod is volgens Jesus liefde tot God en liefde tot die naaste en hierin word Hy deur verskeie uitsprake in die Nuwe Testament nagevolg soos Romeine 13:8 en 1 Johannes. Uit hierdie verwysings is dit duidelik dat die outeurs van die Heidelbergse Kategismus nie 'n kunsmatige tweedeling van die wet in die oog het nie, maar dat hulle op die liefde as die vervulling van die wet wil wys. Dit gaan in die wet om die liefde tot God en die liefde tot die naaste. Die liefde is die goue draad wat deur die hele wet loop.

Die wet is die kenbron van die mens se ellende, die tugmeester tot Christus en die reël van gelowiges se dankbaarheidslewe - so word die wet in Sondag 44 van hierdie belydenisskrif beskryf. Die Heidelbergse Kategismus plaas egter spesifiek die behandeling van die wet in dié deel wat oor die dankbaarheidslewe handel. Hierdeur val die klem op die liefde as die motivering en leidinggewende beginsel in die uitvoering van die wet. Die wet het dus nie die karakter van 'n veroordelende en ' $n$ vergeldende gesindheid van God teenoor die mens nie, maar van 'n appelerende oproep om soos nuwe mense te lewe wat deur Christus van die vloek van die wet vrygemaak is (Ridderbos 1971:307). Die opdrag aan die gelowiges tot ' $n$ etiek van liefde in al hulle verhoudings word dus deur die liefdesgebod gemotiveer. Die gedrag van gelowiges moet gemotiveer word deur die liefde wat saam met die geloof die groot opdrag, maar ook die gawe van God aan die mens is. Hoewel die gebooie in die tweede en derde gebod na die straf van God verwys wanneer die gebooie oortree word, is straf en vergelding nie die hoofmotief vir die uitvoering van die wet nie. Die hoofmotief is die liefde wat die gees en karakter van die etiek van liefde omskryf.

\section{Die uitvoering van die wet onder leiding van gebed}

Die etiek van liefde wat deur die Heidelbergse Kategismus aan die orde gestel word, word duidelik namate die belydenisskrif die gebooie een vir een kortliks verklaar. Soos die geval is met die sinekdogeekarakter van die wet, moet die verklarings in die Heidelbergse Kategismus ook gelees word as oproepe aan die volk van God om in die volle lewe met al sy komplekse verhoudings liefde teenoor God en die naaste te betoon. Hierdie appelerende oproepe tot 'n etiek van liefde word vervolgens uitgelig in die behandeling van die belydenisskrif se verklaring van die wet soos dit in Sondag 34 tot 44 weergegee word.

\section{Liefde vir die verbondsgemeenskap}

Die eerste gebod behandel volgens die Heidelbergse Kategismus, die ware godsdiens. Ware godsdiens impliseer die regte verhoudings. Die verhouding met God staan sentraal, maar deur die verhouding met God leef die kinders van God ook in besondere verhoudings met hulle naaste en met God se skepping. Gelowiges leef nie in 'n vertikale verhouding met God en 'n horisontale verhouding met die naaste en die skepping nie. Dit moet eerder gesien word as 'n meerdimensionele driehoeksverhouding waarin die verhoudings ineengevleg is. Hierdie ineengevlegte driehoeksverhouding kan ook die verbondsgemeenskap genoem word (Vriezen 1966:191). Die bedoeling van die eerste gebod is om God alleen te dien en te eer. Op hierdie wyse handhaaf gelowiges die verbondsgemeenskap. Wanneer God nie gedien word nie, kan daar geen sprake wees van 'n verbondsgemeenskap nie. Die teendeel is ook waar: wanneer die verbondsgemeenskap versteur word, word die eer van God in die gedrang gebring. Dan is daar sprake van 'n verbondsbreuk en sonde. Hierdie verbondsbreuk kom aan die lig wanneer gelet word op die Christelike leer oor die gevolge van die sonde en die sondevergifnis. Sonde skend die verbondsgemeenskap. Wanneer God sonde vergewe en sy kinders hulle naaste vergewe, word die verbondsgemeenskap waaroor dit in die eerste gebod gaan, herstel. Waar sonde die verbondsgemeenskap skend, herstel vergiffenis as die konkretisering van versoening, die verbondsgemeenskap (Hauerwas 1983:39; Jones 1995:59). Die implikasie van die eerste gebod is dus om die verbondsgemeenskap te koester.

In hierdie verband beklemtoon die Heidelbergse Kategismus (HK 2003:61) twee sake, naamlik die vermyding van alle afgodery en die lewensindiensstelling aan God. Afgodery vind plaas wanneer mense die verbondsgemeenskap skend, met ander woorde wanneer hulle enigiets in die geskape werklikheid sentraal in hulle lewens stel en hulle lewens daardeur in beslag laat neem. Hierdie afgodery kan bestaan uit towery, waarsêery, bygeloof en die aanbidding van heiliges, maar weens die sinekdogeekarakter van hierdie gebod, gaan dit verder deur alles af te wys wat die mens tot 
lewensbepalende beginsels verabsoluteer en waardeur die verbondsgemeenskap versteur word.

In hierdie verband kom die mens se neiging tot die vorming van lewensbepalende ideologieë in die gesigsveld. Afgodery of verbondsbreuk dui dus ook op ideë en stelsels waaraan mense hulle lewens wy en waarvan hulle hulle heil en sekerheid verwag. Bonhoeffer (1995:77) het gelowiges se оё oopgemaak vir die vernietigende en dehumaniserende werking van ideologiese verknogtheid. In die verlede het verskeie sulke ideologieë die lewens van miljoene mense bepaal en verwoes. Die groot ideologieë van die twintigste eeu soos die Nasionaal-Sosialisme, Kommunisme en Fascisme in sy verskillende vorms kan hier genoem word. Hoewel die direkte aanbidding van beelde en natuurverskynsels in die modernistiese samelewings afgeneem het, is die verknogtheid aan ideologieë en die verknegting wat daaruit voortvloei 'n kenmerk van die hedendaagse mens se lewenswyse. Materialisme en kapitalisme met die gepaardgaande eksploitasie van die armes, wedywering en die uitbuiting van die natuurlike hulpbronne is 'n sprekende moderne voorbeeld hiervan (Küng 1997:160; Broswimmer 2002:109). Liefde vir die verbondsgemeenskap vrywaar gelowiges van die verabsolutering van sekulêre ideë, die primaat van die wetenskap, hedonisme en die soeke na sekerheid in 'n humanistiese lewens- en wêreldbeskouing. Op hierdie wyse word gelowiges opgeroep om stelling in te neem teen die verslawende magte van die tyd en om vanuit die verbondsgemeenskap met God sosiaal-eties te handel.

\section{Liefde vir die Woordbediening}

Op die oog af lyk dit asof die verklaring van die tweede gebod van die Heidelbergse Kategismus (HK 2003:62) om die verbod op beeldediens gaan. Hiermee saam het die beeldediens wat in die tyd van die Reformasie in die RoomsKatoliek Kerk bestaan het, inderdaad ook aan die orde gekom. God mag nie afgebeeld word nie en beelde mag nie aanbid word nie. Beelde moet ook nie gebruik word om die 'leke' te leer nie. God moet op die regte manier vereer word soos Hy in sy Woord beveel, naamlik dat sy kinders geleer word deur die lewende verkondiging van die Woord. Wat is egter die essensie van hierdie verklaring?

Hoewel die verbod op beeldediens belangrik is, is dit nie die kern van die tweede gebod nie. Die vertrekpunt van die tweede gebod is die belangrikheid van die kennis van die godsopenbaring en die gelowige gehoorsaamheid aan die eise daarvan as die grondslag en rigting van die gelowiges se bestaan. Die belydenis van die noodsaak van die kennis van God is daarom die teologiese vertrekpunt van die Reformasie van Calvyn (2008 Inst. 1.1.1.4; Nederlandse Geloofsbelydenis 2003:5). God word deur die skepping, onderhouding en regering van die wêreld en deur sy heilige en goddelike Woord geken. Die geskrewe Woord openbaar ook dat God beter en in meer besonderhede deur die Vleesgeworde Woord, Jesus Christus geken word. Waters (2010:5) noem die Vleesgeworde Woord die dieptepunt van die Christelike moraliteit. God word dus geken deur die openbaring in die natuur, die geskrewe Woord en die Vleesgeworde Woord. Sentraal hierin staan egter die openbaring in die geskrewe Woord, wat die openbaring in die natuur duideliker maak (Calvyn 2008 Inst. 1.6.1.26). Verder verkondig die geskrewe Woord die noodsaak van die Vleesgeworde Woord vir die redding van die wêreld.

Die essensie van die tweede gebod lê dus in die uitspraak dat God sy kinders deur die 'lewende verkondiging van die Woord wil onderrig'. Die gebod gaan om liefde vir die Woordbediening. Hiermee word die diepste grondslag vir alle Christelike morele handelings gelê. Uiteindelik bied die geskrewe Woord die beginsels vir die etiek en is dit ook die toetssteen van alle etiese kodes en handelings. Sonder die lewende verkondiging van die Woord kan daar nie 'n dinamiese soeke en toepassing van die Christelike etiek wees nie. Liefde vir die Woordbediening bly te alle tye en omstandighede aktueel. Dit geld ook in die kontemporêre kultuur en samelewing met makro-etiese vraagstukke. Die aktuele etiek van die liefde rus op die vaste fondament van die liefde vir die lewende verkondiging van die Woord. Daarom draai die Christelike erediens en godsdiens om die Woordbediening. Aktuele Woordbediening is ten alle tye die sine qua non van toepaslike, vormende en suiwerende Christelik-etiese handelings in alle samelewings. Die lewende verkondiging van die Woord impliseer dus onder andere leiding aan gelowiges om sosiaal-eties betrokke te wees en om betekenisvolle rigtingwysers op hierdie gebied aan te bied.

\section{Liefde vir die heiligheid van God en die waardigheid van mense}

Die Heidelbergse Kategismus, Sondag 36 en 37 (2003:62) koppel die lastering van die Naam van God aan vloekery, die misbruik van die Naam van die Here en 'n onnodige eed. Gevolglik word die etiek van die eed behandel. Die eed is aanvaarbaar solank dit die waarheid bevestig en tot heil van die naaste dien. Op grond van die wyse waarop die eed in die $\mathrm{Ou}$ en Nuwe Verbond gebruik is, kan die eed vandag nog in regspraak gebruik word. Die Naam van God moet ook nie in menslike taalhandelings gelaster en misbruik word nie. Hieroor is die verklaring van die Heidelbergse Kategismus (2003:63) duidelik. Ursinus (1978:306) bespreek hierdie perspektiewe uitvoerig binne die konteks van die lewensmilieu van die sestiende eeu.

Die kern van die verbod in die derde gebod lê egter veel dieper as net die eed en die direkte lastering en ydelike misbruik van die Naam van die Here. Hierdie dieper betekenis kom aan die lig wanneer die bybelse getuienis oor die Naam van God ondersoek word. God se Naam openbaar sy Wese (Brunner 1949:120; Routledge, 2008:81). Brunner (1949) stel dit soos volg:

The 'Name' is that which is peculiar to Himself, it is that which distinguishes Him from all else, that which cannot be expressed by any general conception; which is not an object of human knowledge of any kind; we cannot discover it. (bl. 120) 
In Vermeer (1972:204) se klassieke kommentaar op die Heidelbergse Kategismus word hierdie grondbeginsel breedvoerig bespreek en as die grondbeginsel van die verstaan van hierdie gebod aangedui. Ander verklarings volg hom hierin na. God se Naam is die openbaring in sy werke van skepping en verlossing (Douma 1996:76). Sy naam is YHWH wat beteken 'Ek is wat Ek is' (Eks 3:14). Dit word gekwalifiseer deur die uitdrukking, 'God is liefde' (1 Joh 4:16). Die Naam van God druk primêr sy liefdevolle en genadige omgaan met die skepping uit. Hy voorsien, Hy versorg, Hy ontferm en vertroos, Hy is lankmoedig en bowenal verlos en maak Hy nuut. Selfs sy oordele is dade van liefde.

Kwaad, daarenteen, staan teenoor hierdie wesenseienskappe van God; so ook haat en geweld as die teenpole van liefde. Doodslag was immers die eerste gebod wat God in Genesis 9:6 ingestel het. Daarin rus alle ander gebooie (Barth 1961:344). God se Naam word dus aangetas in enige taalgebruik waarin die mens liefdeloosheid uitdruk. Taal wat liefdeloosheid uitdruk, gaan in teen die liefde as die Wese van God en so word God se eer aangetas. Die ontering van God se Naam vind ook plaas wanneer die waardigheid van mense in skeltaal aangetas word (Spr 17:5; Lev 19:14). Vloekery, beledigings en verbale aantasting van ander mense is die aantasting van God se eer. Dit is ook 'n aantasting van die waardigheid van mense wat na die beeld van God geskape is (Jak 3:9).

Die Heidelbergse Kategismus se beklemtoning van vloekery as 'n oortreding van die derde gebod is van wesenlike belang in moderne verhoudings. Alle samelewingsverhoudings, byvoorbeeld huweliks- en gesinsverhoudings, asook arbeids-, rasse- en etniese verhoudings staan of val by mense se verbale omgaan met mekaar. Haatspraak belaster God en dryf mense uitmekaar. Die derde gebod stel dus met die beginsel van ontsag en eerbied vir God ook 'n besondere norm vir interpersoonlike verkeer wat in die hedendaagse sosiale etiek van groot waarde is.

\section{Liefde vir die gemeenskap van die heiliges}

Die Heidelbergse Kategismus (2003:64) se verklaring van die vierde gebod stel 'n heeltemal nuwe Nuwe-Testamentiese perspektief op die gebod om die Sabbat te heilig. Niks word oor arbeid en rus gesê nie, maar wel oor hoe die dag gevul moet word en voortvloeiend daaruit die eis tot daaglikse bekering. Die rusdag word beskryf as die dag waarop die gelowiges moet saamkom om die erediens in stand te hou (Ursinus 1978:329). Hierdie beskrywing wys op die liefde wat gelowiges moet toon vir die gemeenskap van die gelowiges in hulle gesamentlike aanbidding van die Here. Die etiek van arbeid en rus word nie deur so 'n beskrywing uitgesluit nie. Die kommentaar op die tien gebooie deur Douma (1996:112) en De Bruyn (1992:104) dui dit ook sodanig aan. Die liefde vir die gemeenskap van die heiliges is egter ' $n$ besondere beklemtoning van die altydgeldende relevansie van die samekoms van die gemeente in die kerkdiens, die prediking van die Woord, die bediening van die sakramente en die liefdesdiens.
Hierdie verklaring deur die Heidelbergse Kategismus het ingrypende ekklesiologiese implikasies. Die belangrikheid van die geïnstitueerde kerk, die grondbeginsels van die gereformeerde liturgie en die essensie van die ampsbediening word aan die orde gestel. Die Sondag word onderhou deur die gesamentlike aanbidding deur die gemeenskap van die gelowiges rondom die 'vaste punte' van die amptelike bediening van Woord en sakramente. Hierdie handeling moet gelowiges daartoe bring om 'n lewe van daaglikse bekering te volg. Die beoefening van die gemeenskap van die gelowiges in die erediens op die eerste dag, is die voorbereiding vir die lewe as diens aan God. Die erediens moet dus in die lewe van elke dag invloei en op hierdie wyse het die erediens sosiaal-etiese implikasies. Hiermee sny die Heidelbergse Kategismus die moderne idees van 'ongeorganiseerde godsdiens', 'buite-kerklike Christendom' en 'kerk buite die kerk' soos dit in die moderne ekklesiologie sedert Sölle (1967:117) gepropageer is, by sy wortel af. Die rol en betekenis van die geïnstitueerde kerk in die daaglikse lewe van God se kinders as geloofsversterkende en lewensmotiverende instelling, word duidelik beklemtoon. Erediens en die lewe word organies verbind en liefde vir die erediens mond uit in verantwoordelike sosiaal-etiese handelings.

\section{Liefde vir gesag}

Die Heidelbergse Kategismus (2003:64) betrek die vyfde gebod op alle gesagsverhoudings. Hoewel die gebod slegs van gehoorsaamheid uit liefde vir die vader en die moeder spreek, word die gebod vanweë die sinekdogeekarakter van die wet op alle gesagsverhoudings in die samelewing betrek (Beets 1941:294). Die kinders van die Here moet aan hulle ouers, maar ook almal wat oor hulle aangestel is, eer, liefde en trou bewys. Hiermee word die gesin as die kleinste kring van 'n gesagsverhouding uitgelig (Douma 1996:162). Die gesag moet in die gesin gehandhaaf word, want die ordelike gesin is die bousteen van 'n ordelike samelewing. Alle ander gesagsverhoudings in die samelewing kom egter ook ter sprake. Gesagsverhoudings en mense se liefde daarvoor is die voorwaarde vir die ordelike samelewing van mense. Die belofte in hierdie gebod wys daarop. Gesagsloosheid en disrespek vir gesag wat reg en billik toegepas word, bring daarenteen chaos en onvrede.

In die tyd van die Reformasie is die gesag van die staat bevraagteken en selfs deur die Anabaptiste weerstaan (Walker et al. 1992:449). Hierdie opstand het tot baie politieke onrus gelei (Witte 2007:52). Hierteenoor het die volgelinge van die Reformasie die gesag van die owerhede erken en in geskrifte vir die handhawing daarvan gepleit. Opstand teen die owerheid is slegs geduld wanneer die owerheid aktief die koninkryk van God ondermyn en dan ook alleen wanneer ander weë van protes uitgeput is (Calvyn 2008 Inst. 4.20.24.984). Die samelewingsleer van die Reformasie het die burgerlike owerheid hoog aangeslaan en deurgaans liefde vir die burgerlike owerheid bepleit op grond van die belydenis dat alle gesag van God af kom en dat onderdane die gesag dus moet respekteer. Die owerhede moet egter 
die gesag waardig wees en verantwoordelik hanteer sodat mense ' $n$ rustige en vreedsame lewe kan lei en die menslike lewe verryk kan word (Barth 1948:107). Wanneer die burgerlike gesag in stand gehou word, bring dit vrede in die kerk en staat. Hierdie sosiaal-etiese perspektief wat op die reformatoriese teologiese denke gegrond is, vorm die agtergrond vir die Heidelbergse Kategismus se verklaring van die vyfde gebod.

In die kontemporêre samelewing is hierdie verklaring uiters aktueel. Die moderne sekulêre etiek se aftakeling van die heteroseksuele monogame huwelik soos deur God ingestel is, die beklemtoning van die reg van stakings ten koste van die verantwoordelikheid tot produktiewe arbeid, die demokratisering van gesagsverhoudings in die arbeidsveld en by opvoedingsinstellings, maak 'n etiek van liefde soos in die verklaring van die vyfde gebod vervat is, baie relevant en toepaslik in die sosiaal-etiese besinning oor gesag en gesagsverhoudings.

\section{Liefde vir die lewe}

Die Heidelbergse Kategismus (2003:64-65) se verklaring van die sesde gebod gebied in die eerste plek liefde teenoor die naaste wat in geduld, sagmoedigheid, barmhartigheid en vriendelikheid na vore moet kom. Alles wat die naaste kan benadeel, moet voorkom word en ook aan die vyand moet goed gedoen word. Hiermee verwoord die belydenis die liefde wat saam met die liefde tot God die groot gebod genoem word en wat ' $n$ belangrike openbaringslyn dwarsdeur die Skrif is. Die teendeel van liefde is haat, wraaksug, woede en afguns en so 'n gesindheid versteur die vrede van die verbondsgemeenskap en die vreedsame sosiale verhouding.

Deur die toepassing van die liefde ontwikkel die gelowige respek vir die lewe. Daarom kan geoordeel word dat dit in hierdie gebod primêr gaan om die liefde vir die lewe wat die kind van God moet betoon. Lewe is die groot skeppingsgawe van God. Nie alleen is die mens waardig na die beeld van God geskape nie, maar die mens ontvang ook die asem van die lewe en dit maak mense meer as blote biologiese wesens (vgl. Preuss 1991:161; Brueggemann 1977:450; Brueggemann et al. 1999:51; Vriezen 1966:440; Gunkel 1977:6). Die menslike lewe is heilig en moet beskerm word.

In die veld van die teologiese etiek het bioetiese vraagstukke met die ontwikkeling van die lewenswetenskappe baie aktueel geword. Die opkoms van stamselnavorsing en die daaruitvoortvloeiende moontlikhede van genetiese manipulasie en kloning is een voorbeeld hiervan (vgl. Rheeder 1999; Gruen et al. 2007). Daarbenewens word oor genadedood in die aktiewe sin toenemend gedebatteer (Allman 1998:22; Tristan Engelhardt 1998:115). Dwarsoor die wêreld word 'n moratorium op die doodstraf deur die Verenigde Nasies bevorder (Chirac 2001:7). Die aborsiedebat in Suid-Afrika het net hewiger geword na die aanvaarding van die wet op die terminering van swangerskappe en die latere wysiging daarvan om die reg op keuse tot 14-jarige meisies uit te brei. In hierdie diskoerse stel die etiek van die liefde, in hierdie geval die liefde vir die lewe, die prinsipiële vertrekpunt vir 'n teologies-etiese standpunt. Ook in hierdie opsig is die Heidelbergse Kategismus se verklaring van die sesde gebod baie aktueel en toepaslik in die hedendaagse sosiaal-etiese besinning.

\section{Liefde vir die huwelik}

Die Heidelbergse Kategismus bied sterk uitspraak teen seksuele losbandigheid in die verklaring van die sewende gebod (HK 2003:65). Alle onkuisheid moet gehaat word, omdat dit deur God vervloek is. Kinders van die Here moet kuis en ingetoë lewe binne en buite die huwelik. Die oproep tot kuisheid word begrond in die Skrifuitsprake dat die menslike liggaam 'n tempel van die Heilige Gees is en dat dit rein en heilig bewaar moet word. Alles wat tot onkuisheid kan aanleiding gee soos woorde, gebare, gedagtes en luste, word verbied.

Hierdie gebod handel oor die liefde wat die mens moet betoon vir die huwelik as skeppingsinstelling van God. Die huwelik is 'n monogame, heteroseksuele verhouding (Douma 1993:113). Seksualiteit hoort binne die geborge ruimte van so 'n huwelik tuis. Daarin vind seksualiteit sin en betekenis. Die huwelik is ' $n$ verbond, nie net tussen die man en die vrou nie, maar tussen die man, die vrou en God in Christus (Ef 5:21-33; Kol 3:18-19; 1 Pet 3:1-7; Köstenberger 2004:31). In die Reformasie en in die ontwikkeling van die reformatoriese samelewingsbeskouing daarna is die gedagte van die huwelik as verbond uitgebou. Die onlangse artikel van Stackhouse (2005:153) bespreek hierdie ontwikkeling uitvoerig. Hierdie verbondskarakter van die huwelik hou in dat die huweliksverhouding ' $n$ heilige verbintenis is wat deur heiligheid, permanensie (ewige trou), intimiteit en gemeenskaplikheid gekenmerk moet word (Köstenberger 2004:91). Met owerspel word hierdie trou afgesweer en die verbond daardeur verbreek (Bosman 2004:274). Egbreuk word daarom afgewys. Die huwelik as skeppingsinstelling vorm die fondament van die kerk en die staat as samelewingsverbande. Die verklaring van die vyfde gebod wys hierop.

Die oproep tot liefde vir die huwelik is eweneens aktueel in die hedendaagse sosiaal-etiese diskoers oor die huwelik en seksualiteit. Alternatiewe huwelike wat as blote kulturele instellings beskou word wat vir verandering moet oop wees, word aan die orde gestel en as aanvaarbaar beskou (vgl. Dreyer 2008:499). Nuwe vorms van huwelike word as blote sosiale konstruksies, eie aan die kontemporêre samelewing, gesien. Hieronder tel saamblyverhoudings, dit wil sê seksuele verhoudings waarin die paar nie in 'n wetlike verbintenis in die eg verbind is nie asook burgerlike verbintenisse van mense van dieselfde geslag. Die etiek van liefde in die Heidelbergse Kategismus bied 'n goeie grondslag waarin oor die aard, rol en betekenis van die huwelik vir vandag besin kan word en hoedat daar uitdrukking gegee kan word aan die verbondskarakter van die huwelik met die heiligheid, trou en funksionele differensiasie tussen die man en die vrou wat daarmee saamgaan. Liefde vir die huwelik 
sal die patriargale en androsentriese huwelikshouding ook belig en beoordeel of hierdie vorm van huweliksverhouding, wat nog in baie Christelike gesinne voorkom, die toets van menswaardigheid, eie aan die verbond tussen God en sy beelddraers, kan deurstaan.

\section{Liefde vir privaatbesit en die arbeid}

Die Heidelbergse Kategismus (2003:66) verklaar die agtste gebod sodanig dat God alle wyses veroordeel waarop 'n mens die besit van jou naaste, dus ook alle besit wat nie aan jou behoort nie, op 'n onregmatige wyse bekom. Dit sluit in diefstal, bedrog en korrupsie, hetsy deur geweld of die skyn van reg. Die skyn van reg sluit oneerlike handelstransaksies in waar mense byvoorbeeld woekerwins genereer. Die wortel van diefstal en wat daarmee saamgaan, naamlik gierigheid, word verbied. Voorts mag die materiële gawes van God aan die mens nie misbruik of verkwis word nie. Die gebod vereis liefde vir die belange van die naaste en die opdrag om getrou te arbei sodat 'n verdienste deur arbeid verkry word en die nooddruftige daardeur ook versorg kan word.

Twee sake, naamlik die feit dat mense besittings mag hê en dat die mens deur arbeid 'n verdienste moet kry, staan in hierdie verklaring sentraal. Die reg tot privaatbesit is ' $n$ beginsel wat in bybelse tye gegeld het en waaraan God legitimiteit verleen. Hieraan gee Douma (1996:298) breedvoerig aandag in sy bespreking van die agtste gebod. Die reg op privaatbesit is daarom deur die eeue heen in die Christendom erken. Hierdie privaatbesit geld vir intermenslike verhoudings en die burgers se verhouding tot die owerhede. Die mens het nie enige reg op besit teenoor God nie, omdat alles aan die Here behoort. Hierdie twee beginsels rig die mens se omgaan met besittings. Aan die een kant mag mense hulle besittings vermeerder of verminder en van die owerhede verwag om hulle in hierdie aktiwiteite met wetgewing te beskerm. Aan die ander kant is mense teenoor God rentmeesters wat hulle besittings in diens moet stel van die groot geregtigheidsbeginsels van die koninkryk. Die Christelike etiek sal daarom nóg 'n ongebreidelde sosialisme (alles behoort aan die staat), nóg 'n ongebreidelde kapitalisme (alles draai om wins) kan ondersteun (Douma 1996:300). Hierdie gebod stel dus ook die sosiaal-etiese beginsels waaraan die neo-liberale filosofie van die ekonomie, wat tans in liberale demokrasieë hoog aangeslaan word, getoets kan word.

Arbeidsetiek word ook deur hierdie verklaring van die Heidelbergse Kategismus gereël. Mense moet arbei sodat hulle daardeur in hulle eie lewensonderhoud kan voorsien. Anders gesê: verdienste moet deur produksie verkry word en verdienste en produksie moet in ewewig wees. Arbeiders is hulle loon werd en loon moet deur ewewigtige produksie verdien word. Arbeiders mag aanspraak maak op 'n regverdige loon en mag van die owerheid verwag om hierdie reg te beskerm. Daarteenoor moet alle geldmaakprojekte wat nie op arbeid en die verkoop van kundigheid berus nie, byvoorbeeld dobbelary en woekerwins, afgewys word.
Die etiek van besigheid en arbeid word dus in die agtste gebod aan die orde gestel en die grondslag wat hierin gebied word, kan aktueel op hierdie terreine toegepas word. Vir die kontemporêre Suid-Afrikaanse samelewing is die respek vir privaatbesit en die arbeid eweneens van groot belang. Programme soos grondrestitusie en grondhervorming, asook regstellende aksie kom in hierdie opsig in die gesigsveld. Die etiek van die Heidelbergse Kategismus lewer ' $n$ direkte bydrae tot die etiese diskoerse in hierdie verband (vgl. Vorster 2007:41 \& 77). Dieselfde geld vir arbeidsetiek - 'n terrein wat tans in Suid-Afrika uiters belangrik is binne die konteks van baie nywerheidsonrus en stakings.

Ten opsigte van die stryd teen korrupsie geld dieselfde beginsel. Korrupsie vind plaas as 'n intensionele, onwettige en immorele handeling met die doel om een of ander vorm van bevoordeling te verkry (Webb 2005:153; Anderson 2008:198; Dassah 2008:38 \& Mafunisa 2007:261). In SuidAfrika is daar tans 'n hewige diskoers oor die definiëring, bestuur en bestryding van korrupsie in die publieke en in die privaatsektore, juis vanweë die hoë voorkoms daarvan en die gebrek aan deeglike etiese sleutels om die probleem by te lê. Ook in hierdie verband bied die Heidelbergse Kategismus die sleutel tot 'n verantwoordelike bydrae tot die diskoers (vgl. Vorster 2012:133).

\section{Liefde vir die waarheid}

Die Heidelbergse Kategismus (2003:66) stel in die verklaring van die negende gebod die liefde vir die waarheid sentraal. God veroordeel alle valse getuienis, laster, verdraaiing van woorde of ligvaardige en onverhoorde oordeel. Dit word as die werke van die duiwel beskryf. Valsheid verwek die toorn van God. Van die gelowiges word opregtheid vereis en ook die beskerming van die goeie naam van hulle naaste.

In sy verklaring van die negende gebod betrek Douma (1996:313) die verbod veral op regspraak, hoewel hy ook die ander sake wat die Heidelbergse Kategismus noem, bespreek. Ursinus self betrek die gebod veral op die 'waarheid wat onder mense moet geld' (Ursinus 1978:432). Waarheid onder mense waarborg goeie verhoudings en vrede. Met inagneming van die beklemtoning van Ursinus kan gesê word dat die verbondsgemeenskap tussen God en die mense onder andere binne die ruimte van die waarheid geskied. Waarheid bou op, terwyl die leuen afbreek.

Die negende gebod handel oor liefde vir die goeie sedes binne' $n$ konkrete situasie soos dit ook in al die ander gebooie gebeur. Waarheid, deursigtigheid en verantwoordbaarheid is uiters belangrik in die handhawing van gesonde verhoudings tussen die owerheid en die onderdane en ook in arbeidsverhoudings binne die kontemporêreSuid-Afrikaanse samelewing. Goeie orde en vreedsame naasbestaan kan nie realiseer indien die liefde vir die waarheid nie in alle verhoudings nagejaag word nie. In hierdie verband kan alle vorms van misleiding, weerhouding van die waarheid, gebrek aan verantwoording en verplasing van skuld, wat dikwels in owerheidskringe in hierdie samelewing in die 
getuienis van gelowiges aangaande die negende gebod voorkom, onder die loep geneem word. Prediking van die negende gebod soos die Heidelbergse Kategismus dit verklaar, is die reinigende sout wat 'n verdeelde, wantrouige en toornige samelewing nodig het.

\section{Liefde vir geregtigheid}

Die laaste gebod verbied begeerte, want daar begin die oortreding van al die geledings van die liefde wat die Here van sy kinders vra. 'Selfs die geringste begeerte of gedagte teen enige gebod mag nooit is ons harte opkom nie' en die gelowige moet 'heelhartig vyande van alle sonde wees' (HK 2003:67). God eis gehoorsaamheid aan sy wet. Daar is egter 'n belangrike aksent in hierdie verklaring wat in moderne sosiaal-etiese besinning van belang is. In die verklaring van hierdie gebod word die gelowige ook tot 'n begeerte vir alle geregtigheid opgeroep. Geregtigheid in die Skrif is 'n verhoudingsbegrip en het dus alles te doen met die verbondsgemeenskap waartoe die gelowige in die eerste gebod opgeroep word. Hierdeur sluit die eerste en die laaste gebod by mekaar aan. Geregtigheid word ten nouste aan die geregtigheid van die koninkryk gekoppel (bv. in Jes 11:3-5; Jer 23:5-6; 28:5-6; Eseg 36:25-26 en 37:23-24 en Matt 6:33).

Geregtigheid in die Bybel dui primêr op die herstelde verhouding tussen God en die mens op grond van die soenbloed van Christus. Hierdie verhouding is die ruggraat van die verbondsgemeenskap. Daarsonder is alle ander verhoudings broos. Hierdie herstelde verhouding het egter ook duidelike implikasies vir die verhoudings tussen mense. Geregtigheid vereis dat mense mekaar regverdig en billik moet behandel (Kik 1982:65). Onderdrukking, uitbuiting en verontregting tas die bybelse beginsel van geregtigheid aan (2 Sam 12:1-25; Jer 22:17; Am 4 en 5:7-13; Miga 6:12). Niemand kan sê dat hy God liefhet terwyl hy sy naaste verontreg nie (1 Joh 4:20). Geregtigheid moet nie net in interpersoonlike verhoudings gerealiseer word nie, maar ook in die vestiging van sosio-politieke en ekonomiese strukture (Saladin 1982:216). Eloff (1988:341) bevind in sy etiese studie, op grond van oorwoë historiese en eksegetiese ondersoeke, dat die Skrif die vestiging van institusionele geregtigheid vereis. Die soeke na 'n politieke stelsel wat geregtigheid waarborg, is ' $n$ wesenlike deel van die gelowige se priesterlike roeping. Die vervulling van hierdie roeping impliseer nie noodwendig party-politieke aktiwiteit nie, maar beteken dat die gelowige verantwoordelik aan die daarstelling van 'n regverdige sosio-politieke stelsel moet deelneem. Gelowiges moet hulle stemreg sodanig aanwend dat dit bydra tot 'n regverdige regering wat onder andere deur Calvyn (2008 Inst. 4.20.9.975) op grond van Psalm 82 beskryf word as 'n regering wat 'aan die armes en behoeftiges reg doen'. 'n Gelowige mag nie 'n politieke sisteem ondersteun wat armoede bevorder nie en wat nie die beginsel van geregtigheid eer nie. Die Heidelbergse Kategismus se oproep tot liefde vir geregtigheid is dus eweneens aktueel in Suid-Afrika vandag.

Liefde vir geregtigheid bring gelowiges, benewens ' $n$ lewe van vroomheid, ook binne die strukture waarin hulle leef.
Toepassing van die Heidelbergse Kategismus se oproep tot liefde vir geregtigheid beteken dat die teologiese etiek deurlopend moet besin of die kontemporêre samelewing aan die bybelse eise vir die geregtigheid van die tiende gebod voldoen.

\section{Konklusie}

Die etiese relevansie van die Heidelbergse Kategismus lê ten diepste in die oproep tot liefde vir God en die naaste, wat liefde tot godgegewe morele beginsels impliseer. Hierdie beginsels lê in die handhawing van die verbondsgemeenskap ingebed. Daarmee begin en sluit die wet af. Soos oorsigtelik aangedui, is hierdie beginsels aktueel vir die kontemporêre Suid-Afrikaanse samelewing. Geen lewensterrein of samelewingsverband kan daarvan uitgesluit word nie. Aan die prediker, wat geroep is om ook die leer van die kerk te verkondig, gee dit die basis van 'n indringende samelewingskritiek en dit maak 'n appèl op mense om met liefde vir God en hulle naaste te leef. Die etiek van die Heidelbergse Kategismus is steeds relevant in die moderne samelewing en kan ontgin word om 'n direkte bydrae in die morele opbou van die samelewing van vandag te lewer. As 'n karakteretiek van die liefde, dwing dit elke gelowige om as morele agent in die hedendaagse etiese diskoerse betrokke te wees.

\section{Erkenning Mededingende belange}

Die outeur verklaar dat hy geen finansiële of persoonlike verbintenis het met enige party wat hom nadelig kon beïnvloed het in die skryf van hierdie artikel nie.

\section{Literatuurverwysings}

Allman, R.L., 1998, 'Euthanasia and physician-assisted suicide: A non-conformist reformed reflection', The Journal of Pastoral Care 52(1), 19-31.

Anderson, S., 2008, 'Studying the risk of corruption in the least corrupt countries', Public Integrity 10(3), 193-214. http://dx.doi.org/10.2753/PIN1099-9922100301

Barth, K., 1948, Die Christliche Lehre nach dem Heidelberger Katechismus, Evangelischer Verlag, Zürich.

Barth, K., 1961, Church Dogmatics, Vol. 3: The doctrine of creation, Part 4, Transl. A.T. Mackay et al., Clark, Edinburgh.

Beeke, J.R. \& Ferguson, S.B., 1999, Reformed confessions harmonized: With annotated bibliography of reformed works, Grand Baker Books, Grand Rapids.

Beets, H., 1941, The compendium explained, Eerdmans, Grand Rapids.

Bohatec, J., 1934, Calvin und das Recht, Bohlhaus, Vienna.

Bohatec, J., 1962. Calvins Lehre von Staat und Kirche, mit besonderer Berucksichtigung des Organismus Gedankens, Scientia Aalen, Breslau.

Bonhoeffer, D., 1995, Ethics, Simon \& Schuster, London. PMCid:41066

Bosman, H., 2004, 'Adultery, prophetic tradition and the Decalogue', in W.P. Brown (ed.), The ten commandments, the reciprocity of faithfulness, pp. 209-218, Westminster John Knox Press, London.

Broswimmer, F.J., 2002, Ecocide: A short history of mass extinction of species, Pluto Press, London.

Brueggemann, W., 1977, Theology of the Old Testament, Fortress, Minneapolis.

Brueggemann, W., Petersen, D.L., Freitheim, T.E. \& Bruce, C.B., 1999, A theological introduction to the Old Testament, Abington, Nashville. PMCid:2640814

Brunner, E., 1949, The Christian doctrine of God: Dogmatics, Vol. 1, transl. O. Wyon, Lutterworth Press, London.

Calvyn, J., 2008 [1559], Institutes of the Christian religion, transl. H. Beveridge, Hendriksen, Peabody.

Chirac, J., 2001, Speech by Jaques Chirac, President of the French Republic before the United Nations Commission on Human Rights, United Nations, Geneva. PMid:11303617 
Dassah, M.O., 2008, 'Is there a hole in the bucket? Identifying drivers of public sector corruption, effects and instituting effective combative measures', Journal of Public Administration 43(3.1), 37-62.

De Bruyn, P.J., 1992, Die tien gebooie, Varia, Midrand.

Douma, J., 1993, Seksualiteit en huwelijk, Uitgeverij Van den Berg, Kampen.

Douma, J., 1996, The ten commandments: Manual for the Christian life, transl. N.D. Kloosterman, P \& R Publishing, Philipsburg. PMCid:157868

Dreyer, Y., 2008, 'The "sanctity" of marriage - An archeaology of a socio-religious construct: Mythological origins, forms and models', Hervormde Teologiese Studies 64(1), 499-527. http://dx.doi.org/10.4102/hts.v64i1.10

Eloff, T., 1988, 'Staatsowerheid en geregtigheid met besondere verwysing na rasseklassifikasie: 'n Teologies-etiese studie', Ongepubliseerde ThD-proefskrif, PU vir CHO, Potchefstroom. PMid:3149803

Geisler, N.L., 2010, Christian ethics: Contemporary issues and options, Baker, Grand Rapids.

Grabill, S.J., 2006, Rediscovering the natural law in reformed theological ethics, Eerdmans, Grand Rapids.

Gruen, L., Grabel, L. \& Singer, P., 2007, Stem cell research: The ethical issues, Blackwell, Oxford.

Gunkel, H., 1977, Genesis, 9. Auflage, Neudruck der 3. Auflage von $1910 \mathrm{mit}$ ausfürlichen Registern, Vandenhoeck \& Ruprecht, Göttingen.

Hauerwas, S., 1983, The peaceable kingdom, University of Notre Dame Press, Notre Dame.

Heidelbergse Kategismus, 2003, Die Heidelbergse Kategismus of onderwysing in die Christelik leer, in Gereformeerde Kerke in Suid-Afrika, Psalmboek: Die berymde en omgedigte Psalms en ander Skrifberymings in gebruik by die Gereformeerde Kerke omgedigte Psalms en ander Skrifberymings in gebruik
in Suid-Afrika, pp. 33-72, NG Kerk-Uitgewers, Paarl.

HK kyk Heidelbergse Kategismus

Hursthouse, R., 2010, 'Virtue Theory', in H. Lafolette (ed.), Ethics in practice, pp. 4555, Blackwell, Oxford.

Jones, L.G., 1995, Embodying forgiveness: A theological analysis, Eerdmans, Grand Rapids.

Kik, A., 1982, Geloof in menschenrechten, Kok, Kampen. PMid:7178486

Köstenberger, A.J., 2004, God, marriage and family: Rebuilding the biblical foundation, Crossway Books, Wheaton.

Küng, H., 1997, A global ethic for global politics and economics, SCM, London.

Leith, J.H., 1989, John Calvin's doctrine of the Christian life, Westminster, Louisville.

Mafunisa, M.J., 2007, 'Corruption and service delivery in the public services: The case of Limpopo Province' Journal of Public Administration 42(3), 260-270.

McNaughton, D. \& Rawling, P., 2010, 'Deontology' in H. Lafolette, Ethics in practice, pp. 31-44, Blackwell, Oxford.

McNeil, J.T., 1965, 'John Calvin and civil government', in G.L. Hunt, Calvinism and the political order, pp. 20-35, Westminster, Philadelphia.
Nederlandse Geloofsbelydenis, 2003, Die drie formuliere van eenheid, Nederlandse geloofsbelydenis, in Gereformeerde Kerke in Suid-Afrika, Psalmboek: Die berymde en omgedigte Psalms en ander Skrifberymings in gebruik by die Gereformeerde en omgedigte Psalms en ander Skrifberymings in gebruik
Kerke in Suid-Afrika, pp. 5-32, NG Kerk-Uitgewers, Paarl.

Preuss, H.D., 1991, Old Testament theology, Vol. 1, Westminster, Louisville.

Rheeder, A.L., 1999, Selektiewe voortplanting by die mens, Ongepubliseerde ThDproefskrif, PU vir CHO, Potchefstroom.

Ridderbos, J., 1971, Paulus: Ontwerp van zijn theologie, Kok, Kampen.

Routledge, R., 2008, Old Testament theology: A thematic approach, InterVarsity, Nottingham.

Saladin, P., 1982, 'Die Rechtsgeltung von Menschenrechten als Beispiel für die Rechtserheblichkeit etischer Kriterien', in A. Hertz et al., Handbuch der Christlichen Ethik, pp. 197-220, Gutersloher Verlaghaus, Freiburg.

Sölle, D., 1967, De waarheid is concreet, Ten Have, Amsterdam.

Stackhouse, M.L., 2005, 'Covenantal marriage: Protestant views and contemporary life', in J. Witte \& J.E. Ellison (eds.), Covenant marriage in comparative perspective, pp. 153-181, Eermans, Grand Rapids.

Tristan Engelhardt, H., 1998, 'Physician-assisted death: Doctrinal developments vs. Christian tradition', Christian Bioethics 4(2), 115-121. http://dx.doi.org/10.1076/ chbi.4.2.115.6909, PMid:11657101

Turretin, F., 1997, Institutes of elenctic theology, Vol. 1, Transl. G.M. Geiger, T \& T Publishing, Phillipsburg.

Ursinus, Z., 1978, Het shatboek der verklaringen van de Heidelbergse Catechismus, Vert. deur F. Hommius en in hedendaagse Nederlands herskryf deur J. van der Haar, J.P. van den Tol, Dortrecht.

Van 't Spijker, W., 2009, The church's book of comfort, Reformation Heritage Books, Grand Rapids. PMCid:2722609

Van Drunen, D., 2010, Natural law and the two kingdoms: A study in the development of reformed social thought, Eerdmans, Grand Rapids. PMCid:2858735

Vermeer, J., 1972, De leer der waarheid, die naar de godzaligheid is voorgesteld, bevestigd en toegepast in 85 oefeningen over de Heidelbergse Catechismus, De Banier, Utrecht.

Vorster, J.M. 2007, Christian attitude in the South African liberal democracy, Potchefstroom Theological Publications, Potchefstroom.

Vorster, J.M., 2012, 'Managing corruption in South Africa: The ethical responsibility of churches', Scriptura 109(2012), 133-147.

Vriezen, T.C. 1966, Hoofdlijnen der theologie van het Oude Testament, Veenman \& Zonen, Wageningen.

Walker, W., Norris, R.A., Lotz, D.W. \& Handy, R.T, 1992, A history of the Christian church, Clark, Edinburgh.

Waters, B., 2010, 'The incarnation and Christian moral life', in F.L. Shults \& B. Waters (eds.), Christology and ethics, Eerdmans, Grand Rapids.

Webb, W., 2005, 'Applying the public service anti-corruption strategy in pursuit of accountable South African public administration', Journal of Public Administration 40(2), 151-165.

Witte, J., 2007, The reformation of rights: Law, religion and human rights in early modern Calvinism, University Press, Cambridge. 